\title{
BPMN Impact on Process Modeling
}

\author{
Przemyslaw Polak \\ Warsaw School of Economics, Department of Business Informatics, \\ Al. Niepodległości 162, Warszawa 02-554, Poland \\ ppolak@sgh.waw.pl
}

\begin{abstract}
Recent years have seen huge rise in popularity of BPMN in the area of business process modeling, especially among business analysts. This notation has characteristics that distinguish it significantly from the previously popular process modeling notations, such as EPC. The article contains the analysis of some important characteristics of BPMN and provides author's conclusions on the impact that the popularity and specificity of BPMN can have on the practice of process modeling. Author's observations also show a strong correlation between analyst's modeling style in BPMN and his previous IT experience.
\end{abstract}

Keywords: Business process modeling, system analysis, business analysis, BPMN.

\section{The development of business process modeling notations}

Modern methods of business process modeling were developed under the influence of solutions stemming from both management science as well as the methods of computer science. In the field of management, process approach became popular in the nineties of the last century. A special role in popularizing this approach played business process reengineering (BPR) $[1,2]$ which evolved into the modern methods of process management [3].

But even earlier in the 70s twentieth century, process modeling became widespread in the structural methods of information systems analysis and design [4, 5]. The development of those methods was due to the growing complexity of IT systems that could no longer be mapped using graphical methods, such as flowcharts which are aimed at representing algorithms implemented in computer programs. The most popular methods for processes modeling originally developed in the seventies include:

- data flow diagrams (DFD),

- process models belonging to the family of IDEF (Integration Definition) models. There are many notations for DFD, the most popular are [6]: Gene \& Sarson, DeMarco-Yourdon and SSADM (Structured Systems Analysis and Design Method). Although, data flow diagrams are now less common, they are still in use both in practice and in teaching computer science and information systems $[7,8]$. 
IDEF, formerly referred to as ICAM (Integrated Computer-Aided Manufacturing) definition, is the group of modeling languages used in systems and software engineering. Although, it was developed for the U.S. Air Force, it is currently in the public domain. Nowadays, the process models of the IDEF family are used, apart from the U.S. Army, mostly in the industrial sector $[9,10]$.

The turn of the eighties and nineties of the twentieth century marked the beginning of the dominance of object-oriented methods in information systems engineering, displacing structural methods [11]. Contrary to this trend, almost simultaneously, the rapid growth of interest in process management resulted in the return of interest in process diagrams $[12,6]$. However, the methodologies and notations used in DFD and IDEF do not fully meet the needs of modern business process modeling, as they were designed for the purpose of modeling systems in software engineering. Also, activity diagrams are not suited for this purpose despite many attempts [11]. In addition, many developers of CASE tools refrained from taking into account the structural methods in future versions of their products [13].

Needs arising from the popularization of the process approach in management led to the development of dedicated software for process modeling, among which were environments such as: Adonis, ARIS Toolset, Corporate Modeler, and iGrafx [14]. However, those tools used different modeling notations. They had many features in common, but in some aspects differed significantly causing confusions. In the first decade of the twenty-first century significant popularity gained EPC (Event-driven Process Chain) notation - an element of the ARIS concept by IDS Scheer's (now Software AG) [15]. That notation was founded in the early nineties of the twentieth century as a result of the joint venture of the Institute of Information Systems at the University of Saarland and SAP. To the popularization of EPC largely contributed its usage for documenting reference processes in the SAP ERP (formerly SAP R/3) system [16].

In recent years, great popularity was achieved by BPMN (Business Process Model and Notation, formerly Business Process Modeling Notation). The first official version of the standard was published in the May 2004. Currently version 2.0 was published in January 2011. This notation has been included in the most popular tools for mapping business processes. Its growing role in the process modeling may lead in future to the total domination of BPMN, like it happened with UML (Unified Modeling Language) in object-oriented modeling [11]. The purpose of this article is to identify how the usage of BPMN can influence the business process modeling practice due to some BPMN features which are considerably different from other popular modeling notations.

\section{Selected features of BPMN}

The assumption that motivated the creators BPMN was that it could be used both by business representatives who want to understand and improve their business processes and by analysts and designers to provide information necessary for the implementation of information systems [17]. Moreover, correctly defined BPMN model can be used to generate BPEL (Business Process Execution Language) code 
for automated implementation. However, in practice, this way of using BPMN is rarely used [18].

Intended versatility allows to distinguish three levels of business process modeling using BPMN [19]:

- descriptive modeling - showing general process structure, without taking into account the details of data processing,

- analytical modeling - used in system analysis to determine system requirements and for analyzing process performance,

- executable modeling - describing thoroughly a process, objects and parameters to correctly generate BPEL code.

However, the BPMN standard does not define these levels. The content of charts at each level depends entirely on analyst's assessment and rules adopted in a particular project [19].

In addition to executable modeling, BPMN have other features associating it with the methods of software engineering. For example, the concept of BPMN is similar to UML activity diagrams [20]. Moreover, one of the postulations of effective and flexible process management support by IT systems is the use of service-oriented architecture (SOA) [21, 22]. And, one of the most highlighted benefits of BPMN is its strong alignment with the needs of system design in SOA [23].

These features correlate the use of BPMN with systems and software engineering. However, BPMN can be used to create general illustrative models for different needs related to the management process. Therefore, the question arises whether BPMN is actually equally well fitted for both areas of usage.

The answer to this problem is BPMN complexity - one of its most characteristic features. BPMN includes 39 basic elements of the language notation, whereas EPC contains only nine such objects [24]. Moreover, BPMN allows the same logical structures to be represented by different notation methods permitted by the standard. As a result, many language elements can be omitted, depending on the level of complexity. On the one hand, this flexibility allows to adjust models to meet specific needs, but it can also be confusing for inexperienced readers.

BPMN standard allows considerable flexibility in the use events. They can be completely ignored, even start and end events. This approach in absolutely different than the ARIS method and EPC notation, in which each function must be preceded by an event and followed by such. As a result, the flow of the process is shown as totally event driven.

In BPMN, the role of events can, in part, be played by messages. Receiving and sending messages can be represented by both tasks and events. However, this feature introduces a lot of flexibility in creating models, and hence, incoherent modeling style can lead to inconsistencies in syntax within a single model, and thus to interpretation difficulties for the reader.

Possibility of omitting all events in the diagrams is also in opposition to the dominant business process presentation practice. The usage of event has been a widely accepted in processes modeling since the nineties. The introduction of eventdriven approach is considered to be the key determinant of the maturity of process modeling methods $[25,26]$.

The rapid growth of BPMN popularity has caused attempts to create the formal comparative model of EPC and BPMN, see inter alia [27, 28], as well as to formulate 
the transformation methods of existing EPC diagrams into BPMN diagrams [29, 30]. However, those studies focus on the formal aspects of those languages. Much rarer are efforts to explore their subjective acceptance by both the creators of models and their recipients [31]. Such an attempt to assess the style of modeling in BPMN is presented further in this article.

\section{The complexity of BPMN and process maps intelligibility}

The complexity of BPMN makes possible excessive complication of the way in which processes are presented in diagrams. The individual style of modeling can strongly affect the clarity of process maps [31].

Some studies suggest, however, that those who are already familiar with one process modeling language should not have any problem with understanding others, in this case, BPMN [24]. It should be noted that in the mentioned study participated information systems students who had been earlier introduced to EPC and other methods of computer science, including programming. Therefore, those conclusions can not apply to persons with no IT background.

On the other hand, some BPMN elements are strictly associated with data processing. Therefore, such elements as a transaction or a compensation event may be appreciated by people with previous experience in systems design and programming. The author observed this phenomenon during post-graduate classes on business process modeling, conducted at the Warsaw School of Economics. The study covered 88 participants of those classes. They were people of different age, between 25 and 50 , some with many years of professional IT experience. Two quite different groups of participants were isolated among them:

- 45 students with previous experience in IT, mainly programmers and systems designers wishing to expand their skills in the business and system analysis,

- 43 students with no earlier IT experience, mostly professionals working in various functional areas of organizations, wishing to acquire competence in the area of information systems analysis and implementation.

During the course, students were introduced to both: EPC and BPMN notations. Students with IT experience were more likely to be involved in discussions on process maps in BPMN, while those with no computer science experience found them more difficult to interpret. In case EPC diagrams, even those with no experience in systems modeling could easily understood those models. Moreover, the EPC diagrams were commented as "too vague and general" by students with programming experience.

Stronger differences in model perception and modeling style in BPMN were observed during the development of process maps by students. Among IT specialists clearly appeared a tendency to create complex, very detailed diagrams. In some cases, even tasks (elementary functions) were decomposed into small processing steps, what caused that those diagrams resembled flowcharts, and the size and complexity of diagrams made them difficult to understand.

Moreover, all study participants, regardless of the status of their earlier IT experience, had a tendency to show on BPMN diagrams too many details of processing, at the same time forgetting the purpose, the client and the main business 
functions of processes. It was observed regardless clear instructions from an instructor to create only descriptive models. However, while working on EPC diagrams on the same examples, such tendency was observed to a much lesser extent.

\section{Conclusion}

The growing popularity of BPMN can lead to the domination of this notation, not only in the creation of system requirements specification, but also in other cases that require process modeling in business processes management. However, many features clearly distinguish BPMN from other process notations. Moreover, some features discussed in this paper disturb the perception and representation of business processes, earlier adopted in management practice.

The popularity of BPMN among information systems analysts and designers can contribute to the better awareness of the process approach in this professional group, what may trigger the better adaptation of information system functions to the principles of process management. At the same time, however, author's observations suggest that the practice of process modeling by analysts with previous IT experience can affect the clarity of process maps for other users, and thus interfere with one of the cornerstones of the process approach - the ability to easily understand and analyze processes by all users within an organization.

\section{References}

1. Davenport, T.H.: Process Innovation: Re-engineering Work through Information Technology. Harvard Business School Press, Boston (1993)

2. Hammer, M., Champy, J.: Reengineering the Corporation. A Manifesto for Business Revolution. Harper Business, New York (1993)

3. Jokiel, G.: Podejście procesowe w zarządzaniu - geneza i kierunki rozwoju koncepcji. In: Nowosielski, S. (ed.) Podejście procesowe w organizacjach. Prace Naukowe Uniwersytetu Ekonomicznego we Wrocławiu nr 52, Wrocław (2009)

4. DeMarco, T.: Structured Analysis and System Specification. Prentice Hall, Englewood Cliffs (1978)

5. Gane, C., Sarson, T.: Structured Systems Analysis: Tools and Techniques. Prentice-Hall, Englewood Cliffs (1979)

6. Whitten, J.L., Bentley, L.D., Dittman, K.C.: Systems analysis and design methods. McGraw-Hill Irwin, Boston (2004)

7. Polak, D., Polak, P.: Zmiany w programie laboratorium $\mathrm{z}$ informatyki gospodarczej na uczelniach ekonomicznych. In: Szewczyk, A. (ed.) Dydaktyka informatyki i informatyka w dydaktyce. Uniwersytet Szczeciński, Szczecin (2006)

8. Tiwari, K., Tripathi, A., Sharma, S., Dubey, V.: Merging of Data Flow Diagram with Unified Modeling Language. International Journal of Scientific and Research Publications, vol. 2, nr 8, (2012)

9. Chin, K.-S., Zu, X., Mok, C.K., Tam, H.Y.: Integrated Integration Definition Language 0 (IDEF) and Coloured Petri Nets (CPN) Modelling and Simulation Tool: a Study on Mouldmaking Processes. International Journal of Production Research, vol. 44, nr 16 (2006) 
10.Kim, C.-H., Weston, R.H., Hodgson, A., Lee ,K.-H.: The complementary use of IDEF and UML modelling approaches. Computers in Industry, vol. 50, $\mathrm{nr} 1, \quad$ (2003) http://dx.doi.org/10.1016/S0166-3615(02)00145-8

11.Polak, P., Wieczorkowski, J.: Rozwój metod modelowania procesów biznesowych dla potrzeb wytwarzania systemów informatycznych. In: Nowosielski, S. (ed.) Podejście procesowe w organizacjach. Prace Naukowe Uniwersytetu Ekonomicznego we Wrocławiu nr 169, Wrocław (2011)

12.Polak, P.: Systems Analysis and Design in Polish Universities Curricula: Structured or Object-Oriented. In: Bajaj, A., Wrycza, S. (eds.) Systems Analysis and Design for Advanced Modeling Methods: Best Practices. IGI Global - Information Systems Reference, Hershey (2009)

13.Wieczorkowski, J., Polak, P., Kamiński, A.: Podejście procesowe we wdrażaniu SIZ narzędzia wsparcia metodyk. In: Niedzielska, E., Dudycz, H., Dyczkowski, M. (eds.) Nowoczesne technologie informacyjne w zarządzaniu, Prace Naukowe Akademii Ekonomicznej we Wrocławiu nr 1081, Wrocław (2005)

14.Kamiński, A., Polak, P., Wieczorkowski, J.: Podejście procesowe we wdrażaniu SIZ narzędzia modelowania procesów biznesowych. In: Niedzielska, E., Dudycz, H., Dyczkowski, M. (eds.) Nowoczesne technologie informacyjne w zarządzaniu. Prace Naukowe Akademii Ekonomicznej we Wrocławiu nr 1081, Wrocław (2005)

15.Mendling, J.: Metrics for Process Models. Empirical Foundations of Verification, Error Prediction, and Guidelines for Correctness. Lecture Notes in Business Information Processing, vol. 6, Springer, Berlin (2009)

16.Curran, T., Keller, G., Ladd, A.: SAP R/3 Business Blueprint: Understanding the Business Process Reference Model. Prentice Hall PTR, Upper Saddle River (1997)

17.Piotrowski, M.: Business Process Modeling Notation. Notacja modelowania procesów biznesowych. Podstawy. Wydawnictwo BTC, Warszawa (2007)

18.Drejewicz, S.: Zrozumieć BPMN. Modelowanie procesów biznesowych. Helion, Gliwice (2012)

19.Silver, B.: BPMN Method and Style. Cody-Cassidy Press, Aptos (2009)

20.List, B., Korherr, B.: An Evaluation of Conceptual Business Process Modelling Languages. In: Proceedings of the 2006 ACM symposium on Applied computing. ACM, New York (2006)

21.Matei, G.: SOA and BPM, a Partnership for Successful Organizations. Informatica Economica, vol. 15, $\mathrm{nr} 4$ (2011)

22.Wieczorkowski, J., Polak, P.: Wsparcie podejścia procesowego przez systemy informatyczne z zastosowaniem koncepcji SOA. In: Nowosielski, S. (ed.) Podejście procesowe w organizacjach. Prace Naukowe Uniwersytetu Ekonomicznego we Wrocławiu nr 52, Wrocław (2009)

23.Scheithauer, G., Hardegen, B.: Requirements Engineering for SOA Services with BPMN 2.0 - From Analysis to Specification. In: Dijkman, R., Hofstetter, J., Koehler, J. (eds.) Business Process Model and Notation. Third International Workshop, BPMN 2011, Lucerne, Switzerland, November 21-22, 2011. Proceedings. Lecture Notes in Business Information Processing, vol. 95, Springer, Berlin (2011)

24.Recker, J.C., Dreiling A.: Does it matter which process modelling language we teach or use? An experimental study on understanding process modelling languages without formal education. In: Toleman, M., Cater-Steel, A., Roberts, D. (eds.) 18th Australasian Conference on Information Systems. Toowoomba (2007)

25.McMenamin, S.M., Palmer, J.F.: Essential systems analysis. Yourdon Press, New York (1984)

26.Yourdon, E.: Modern structured analysis. Yourdon Press, Englewood Cliffs (1989)

27.Kruczynski, K.: Business process modelling in the context of SOA - an empirical study of the acceptance between EPC and BPMN. World Review of Science, Technology and Sustainable Development, vol.7, $\mathrm{nr} 1 / 2$ (2010) 
28.Kunze, M., Luebbe, A., Weidlich, M., Weske, M.: Towards Understanding Process Modeling - The Case of the BPM Academic Initiative. In: Dijkman, R., Hofstetter, J., Koehler, J. (eds.) Business Process Model and Notation. Third International Workshop, BPMN 2011, Lucerne, Switzerland, November 21-22, 2011. Proceedings, Lecture Notes in Business Information Processing, vol. 95, Springer, Berlin (2011)

29.Levina, O.: Assessing Information Loss in EPC to BPMN Business Process Model Transformation. In: Chi, C.-H., Grossmann, G. (eds.) Proceedings of the 2012 IEEE 16th International Enterprise Distributed Object Computing Conference Workshops, IEEE CPS, Los Alamitos (2012)

30.Tscheschner, W.: Transformation from EPC to BPMN. Business Process Technology, vol. $1, \operatorname{nr} 3(2006)$

31.Allweyer, T.: Human-Readable BPMN Diagrams. In: Fischer, L. (ed.) BPMN 2.0 Handbook. Second Edition. Methods, Concepts, Case Studies and Standards in Business Process Modeling Notation (BPMN), Future Strategies Inc, Lighthouse Point (2012) 